\title{
Antimicrobial Activity of Biomolecules from Mushroom Fungi against Colletotrichum capsici (Syd.) Butler and Bisby, the Fruit Rot Pathogen of Chilli
}

\author{
K. Priya, G. Thiribhuvanamala*, A. Kamalakannan and A.S. Krishnamoorthy \\ Department of Plant Pathology, Tamil Nadu Agricultural University, \\ Coimbatore- 641 003, India \\ *Corresponding author
}

\section{Keywords}

Chilli,

Colletotrichum capsici, Ganoderma lucidum, Solvents, Mushroom fungi, Antimicrobial activity, Inhibition per cent

\section{Article Info}

Accepted:

10 May 2019

Available Online:

10 June 2019

\section{A B S T R A C T}

Mushroom fungi secrete antifungal, antibacterial and antiviral bioactive compounds of therapeutic and pharmacological value. Very limited work has been done on the exploration of antimicrobial principles from macrobasidiomycetes against plant pathogens. In this view, a study was proposed to screen eight mushroom fungi viz., Auricularia polytricha, Coprinus comatus, Ganoderma lucidum, Volvariella volvaceae, Lentinus edodes, Pycnoporus sanguineus, Schizophyllum commune, Trametes versicolor against spore germination and mycelial growth of Colletotrichum capsici, the fruit rot pathogen of Chilli and to extract antimicrobial molecules from the selected mushroom fungi using different solvents viz., Chloroform, Diethyl ether and Ethyl acetate. Results from dual culture technique revealed that Ganoderma lucidum, Auricularia polytricha and Lentinus edodes showed maximum antifungal activity by inhibiting the mycelial growth of $C$. capsici $(54.81 \%, 53.70 \%$ and $45.55 \%$ respectively) with maximum inhibition zone of $(4.86 \mathrm{~mm}, 2.86 \mathrm{~mm}$ and $4.86 \mathrm{~mm}$ respectively). Though the Chloroform, Diethyl ether and Ethyl acetate fractions of $G$. lucidum cell free extracts inhibited spore germination of $C$. capsici both at 12 and 24 hours, maximum inhibition of spore germination was observed at 24 hours. Among the mushroom fungi, the chloroform extracted fractions followed by Diethyl ether and Ethyl acetate fractions of G. lucidum cell free culture filtrates exhibited maximum inhibition of spore germination of C. capsici (inhibition of $88 \%, 79 \%$ and $78 \%$ respectively) at 24 hours. Similarly, maximum inhibition of mycelial growth of $C$. capsici with $40 \%, 34.07 \%$ and $29.25 \%$ inhibition respectively was recorded in the chloroform extracted fractions followed by Diethyl ether and Ethyl acetate fractions of G. lucidum cell free culture filtrates when compared to solvent extracted fractions of $L$. edodes and A. polytricha by agar well diffusion technique. The chloroform extracted metabolite of $G$. lucidum followed by Ethyl acetate and Diethyl ether fractions at $2000 \mathrm{ppm}$ concentration inhibited maximum mycelial growth of C. capsici $(60.55 \%, 58.88 \%$ and $55.47 \%$ respectively). It is well proven that chloroform extracted fractions of G. lucidum possess antimicrobial activities against the growth of $C$. capsici. Hence, further studies towards the identification of these compounds will pave for development of fungicides against $C$ .capsici. 


\section{Introduction}

Chilli (Capsicum annum L.) is an important commercial spice crop grown in almost all the states of India with 1.49 million tonnes of dry chilli produced annually (FAOSTAT, 2013). Such an important crop is affected by many diseases including fungi, bacteria and viruses, the most important being anthracnose (fruit rot) disease caused by a complex of Colletotrichum species that cause latent infection and affects ripe fruits (Jeffries et al., 1990) and resulting in both pre and postharvest fruit decay with yield losses of up to $50 \%$ (Liu et al., 2016), about $25 \%$ fruit loss at pre-harvest stage and $25-40 \%$ loss at postharvest stage (Sharma and Shenoy, 2014) and severe losses of $10-60 \%$ both in yield and quality of the chilli (Bansal and Grover, 1969). Among these, Colletotrichum capsici (Syd.) Butler and Bisby is reported to survive in plant debris, spreads through seeds from infected fruits and causes both fruit rot and die back in chillies thereby leading to severe yield reduction. Moreover, secondary spread in the field is favoured at a temperature around $27-28^{\circ} \mathrm{C}$ with relative humidity of 80 per cent through wind borne conidia that aids in fast spread of the disease (Roberts et al., 2001). The intensive use of fungicides has resulted in the accumulation of toxic compounds potentially hazardous to humans and the environment, and also in the build-up of resistance of the pathogens.

As chilli is an edible crop and large quantity of pesticides was being used, there is a growing demand for chemical pesticide free organic chilli world over. Current research is focused on search of antimicrobials from green channels such as plants, fungi and bacteria in order to identify biopesticidal compounds. Perusal of literature showed that apart from food, mushroom fungi are important as natural sources of medicines and possess number of bioactive compounds viz., antibacterial, antifungal, antioxidant, antiviral antinemic, anti- tumor, immunosuppressive, antiallergic, anti-inflammatory activities, hypolipidemic, and hepatoprotective activity (Hatvani, 2001; Wasser, 2002; Lindequist et al., 2005; Reis et al., 2011; Rouhana-Toubi et $a l ., 2015)$. Owing to the current emphasis on the ecofriendly approaches for plant disease management, mushroom fungi can serve as promising source of antimicrobials against plant pathogens as evidenced by the antimicrobial activity of the culture filtrates of Ophiocordeyceps sinensis against soil borne pathogens of Fusarium oxysporum f. sp. lycopersici and F. oxysporum f. sp. cubense (Sangeetha and Krishnamooorthy, 2015), Coprinus comatus against $F$. oxysporum f. sp. brachygibbosum, Fusarium oxysporum f. sp. lycopersici and $F$. oxysporum f. sp. cubense (Jeeva and Krishnamoorhy, 2018), ethanolic extracts of Leucopaxillus gignatea against Aspergillus niger, Fusarium solani, Collectotrichum graminicolum and Helminthosporium maydis, Xanthomonas axanopodis pv. punicae, Pseudomonas syringa and Bacillus subtilis, (Feleke and Anila Doshi, 2017). Perusal of literature showed that no work has been attempted on the exploitation of antimicrobials from mushroom fungi against Colletotrichum capsici and this kindled interest to undertake the present investigation with an aim to identify a potential mushroom fungus with antimicrobial activity against $C$. capsici, the chilli fruit rot pathogen.

\section{Materials and Methods}

The chilli fruit rot pathogen Colletotrichum capsici (Acc. No. MK758061) and the mushroom fungal cultures viz., Ganoderma lucidum, Auricularia polytricha, Lentinus edodes, Coprinus sinensis, Schizophyllum commune, Trametes versicolor, Volvariella volvaceae and Pycnoporus sanguineus obtained from the Department of Plant 
Pathology, Tamil Nadu Agricultural University, Coimbatore were used for the studies.

In vitro screening of mushroom fungi against $C$. capsici

Mushroom fungi viz. Ganoderma lucidum, Auricularia polytricha, Lentinus edodes, Coprinus sinensis, Schizophyllum commune, Trametes versicolor, Volvariella volvaceae and Pycnoporus sanguineus were tested for its antagonistic activity against $C$. capsici by following dual culture technique (Dennis and Webster, 1971). A $9 \mathrm{~mm}$ mycelial disc of mushroom fungi was placed at the edge of the Petri plates containing PDA medium on one side. Similarly, on the opposite side a $9 \mathrm{~mm}$ mycelial disc of $C$. capsici was placed. The dual culture plates were incubated at $28 \pm 2^{\circ} \mathrm{C}$ for 7 days. Three replications were maintained for each treatment. Plates with $C$. capsici only and respective mushroom fungi served as control. The plates were examined periodically and measurements on the radial mycelial growth of $C$. capsici and mushroom fungi were recorded till the control plate attained full growth $(90 \mathrm{~mm})$. The percent inhibition of mycelial growth of $C$. capsici was calculated by using the formula proposed by Vincent (1947).

Percent inhibition of growth $(\mathrm{PI})=\mathrm{C}$ $\mathrm{T} / \mathrm{C} \times 100$

Where, $\mathrm{C}$ is the growth of pathogen in control $(\mathrm{mm})$ and $\mathrm{T}$ is the growth of pathogen in treatment $(\mathrm{mm})$.

\section{Preparation of solvent extracted} metabolites from selected mushroom fungi

Based on the above studies, the mushroom fungi that showed maximum inhibition of mycelial growth of $C$. capsici was selected and used for further studies.
Mycelial discs (measuring $9 \mathrm{~mm}$ dia.) was cut from margin of a 10 day old culture of $G$. lucidum, L. edodes, A. polytricha grown in PDA medium in petridishes and inoculated in $250 \mathrm{ml}$ conical flasks containing $100 \mathrm{ml}$ of sterilized PD broth. The flasks were placed on a rotary shaker maintained at $120 \mathrm{rpm}$ and incubated at $25^{\circ} \mathrm{C}$ for 20 days. After incubation, the culture filtrate and the mycelial mat were separated by filtration through Whatman No. 40 filter paper. The filtrate was further centrifuged at 10,000 rpm and the Cell Free Culture filtrate (CFC) of $G$. lucidum, L. edodes, A. polytricha was extracted separately with three different solvents viz., ethyl acetate, chloroform and diethyl ether. Liquid-liquid extraction was carried out three to four times for each solvent. The ethyl acetate, chloroform and diethyl ether solvent extracts from CFC of $G$. lucidum, L. edodes, A. polytricha was evaporated separately under reduced pressure using a rotary evaporator to obtain the residues. The condensate or residue so obtained from solvent was dried and dissolved in methanol $(1 \mathrm{mg} / \mathrm{ml})$ and filtered with membrane filter $(0.48 \mu \mathrm{m})$, stored at $4^{\circ} \mathrm{C}$ used for further studies.

Effect of different solvent extracted metabolites from selected mushroom fungi on spore germination and mycelial growth of C. capsici

\section{Spore germination test}

The different solvent (chloroform, diethyl ether, ethyl acetate) extracted metabolites of G. lucidum, L. edodes, A. polytricha were tested separately against spore germination of C. capsici using cavity slides (Anonymous, 1943).

A drop of chloroform, diethyl ether and ethyl acetate solvent extracted metabolites of $G$. lucidum, L. edodes, A. polytricha were placed 
separately in a cavity slide and a drop of spore suspension $\left(1 \times 10^{6}\right.$ spores $\left./ \mathrm{ml}\right)$ of $C$. capsici prepared in sterile distilled water was added to each of the solvent extracted metabolite and thoroughly mixed. The cavity slide was placed in the Petri dish moistened with cotton and incubated at room temperature (28 \pm $2^{\circ} \mathrm{C}$ ). Three replications were maintained for each treatment. The spore suspension in sterile water alone served as control. The spore germination was observed and recorded after 6, 12 and 24 hours under phase contrast microscope and the percent inhibition of spore germination was calculated using the formula (Akhter et al., 2006).

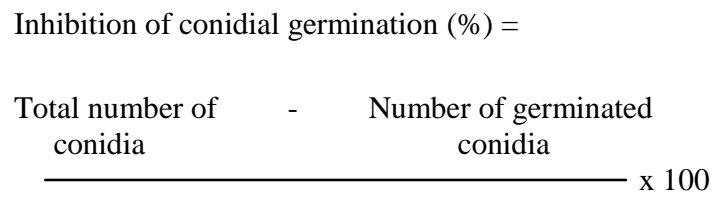

\section{Mycelial growth inhibition test}

The different solvent (chloroform, diethyl ether, ethyl acetate) extracted metabolites of G. lucidum, L. edodes, A. polytricha were tested separately against mycelial growth of C. capsici by agar well diffusion method (Stroke and Ridgway, 1980). After solidification of PDA medium in Petri dishes, four wells $(5 \mathrm{~mm}$ in diameter) were made on the plate using sterile cork borer on all four sides, giving equal distance and also by leaving one $\mathrm{cm}$ space from the periphery. The concentration of solvent extracted (chloroform, diethyl ether, ethyl acetate) metabolites of G. lucidum, A. polytricha and L. edodes were made up to $500 \mathrm{ppm}$ and poured into agar wells at the rate of $100 \mu 1$ per well using micro pipette. Then, mycelial disc of $C$. capsici (5mm diameter) taken from ten days old culture was placed at the centre of each Petri dish and incubated at $28 \pm 2^{\circ} \mathrm{C}$ for seven days. Observations on the per cent inhibition of mycelial growth of $C$. capsici were recorded (Vincent, 1947).
Effect of different concentrations of solvent extracted metabolites of $G$ lucidum on mycelial growth of $C$. capsici by Agar well diffusion assay

Based on the above studies, Ganoderma lucidum was identified to possess maximum antimicrobial activity against $C$. capsici and used for the studies. Different solvents viz., chloroform, diethyl ether and ethyl acetate extracted metabolites from culture filtrate of Ganoderma lucidum were prepared as mentioned earlier. The solvent extracted metabolites of $G$. lucidum were made up to 1000, 1500 and $2000 \mathrm{ppm}$ and used for testing the Minimum Inhibitory Concentration (MIC) of the metabolites that could inhibit the mycelial growth of $C$. capsici by agar well diffusion assay.

\section{Results and Discussion}

Though it is well proven that mushrooms are used as food and in pharmaceuticals since ancient times, the recent research has proved that the mushroom fungi possess secondary metabolites of antimicrobial nature to be effective against many plant pathogens. There is great scope for developing biopesticidal molecules from mushroom fungi that can be used for development of fungicides in plant disease management. The best evidence is the fungicide Azoxystrobin derived from mushroom fungi Strobilurus tenacellus effective against downy mildew and powdery mildew of grapes. Since the last decade, lot of work has been initiated on the identification of antimicrobial metabolites from mushroom fungi against clinical pathogens especially bacteria. Very limited work has been done on the fungal plant pathogens. The easiest and most reliable way to assess the antagonistic potential of mushroom fungi has to be done by dual culture test (Dennis and Webster, 1971) where the growth nature of the mushroom fungi and test pathogen will give 
an indication of the presence or absence of antimicrobial activity of the mushroom fungi.

In vitro screening of mushroom fungi against $C$. capsici by dual culture technique

In our study, among the mushroom fungi tested, Pycnoporus sanguineus, followed by Ganoderma lucidum and Auricularia polytricha showed reduced mycelial growth of C. capsici $(49 \mathrm{~mm}, 40.67 \mathrm{~mm}$ and 41.67 $\mathrm{mm}$ respectively) when compared to control $(90 \mathrm{~mm})$ with inhibition per cent of 57.41, 54.81 and 53.70 respectively. Other mushroom fungi, Lentinus edodes, Trametes versicolor, Volvariella volvaceae and Coprinus sinensis also showed mycelial growth inhibition of $C$. capsici with 45.55 per cent, 43.63 per cent, 42.92 per cent and 40 per cent respectively. However, inhibition zone was maximum $(4.86 \mathrm{~mm}$ and $4.86 \mathrm{~mm})$ in $G$. lucidum and $L$. edodes respectively followed by $A$. polytricha $(2.76 \mathrm{~mm}), V$. volavceae $(2.83 \mathrm{~mm})$ and $T$. versicolor $(1.1 \mathrm{~mm})$ (Table 1; Plate 1). The interactions between respective mushroom fungi and C.capsici in dual culture technique is furnished below.

Interactions between mushroom fungi and $C$. capsici

\begin{tabular}{|c|c|}
\hline Mushroom fungi and Pathogen & Nature of Interaction \\
\hline Ganoderma lucidum and $C$. capsici & $\begin{array}{l}\text { Clear inhibition zone of } 4.86 \mathrm{~mm} \text {; both mushroom } \\
\text { fungi and pathogen did not grow over each other } \\
\text { even after } 10 \text { days }\end{array}$ \\
\hline Auricularia polytricha and $C$. capsici & $\begin{array}{l}\text { Initially clear inhibition zone of } 2.76 \mathrm{~mm} \text {; later } \\
\text { mushroom fungi hyperparasitised over the pathogen }\end{array}$ \\
\hline Lentinus edodes and $C$. capsici & $\begin{array}{l}\text { Pathogen growth was retarded and pushed back with } \\
\text { an inhibition zone of } 4.86 \mathrm{~mm}\end{array}$ \\
\hline Trametes versicolor and C. capsici & $\begin{array}{l}\text { Inhibition zone of } 1.10 \mathrm{~mm} \text {; both pathogen and } \\
\text { mushroom fungi did not grow over each other }\end{array}$ \\
\hline Pycnoporus sanguineus and C. capsici & $\begin{array}{l}\text { No inhibition zone, but thick mat was formed at the } \\
\text { contact of both fungi; later mushroom fungi } \\
\text { hyperparasited over the pathogen }\end{array}$ \\
\hline Schizophyllum commune and C. capsici & $\begin{array}{l}\text { No inhibition zone; but hyperparasitization of } \\
\text { mushroom fungi over pathogen }\end{array}$ \\
\hline Coprinus sinensis and $C$. capsici & $\begin{array}{l}\text { No inhibition zone, thick mat formed between both } \\
\text { fungi }\end{array}$ \\
\hline Volvariella volvaceae and C. capsici & $\begin{array}{l}\text { No inhibition zone, both fungi did not grow over } \\
\text { each other }\end{array}$ \\
\hline
\end{tabular}

Similar to our study, Badalyan et al., (2014) reported the antagonistic activity of Pleurotus ostreatus, Hypholoma fasciculare, Ganoderma lucidum, Lentinus tigrinus and Schizophyllum commune Cochliobolus sativus, Fusarium culmorum, Gaeumannomyces graminis and Rhizoctonia cerealis by dual culture technique. Constituents of Ganoderma and Agrocybe aegerita was found to reducing local lesions of Ground nut bud necrosis virus in cowpea (Sajeena and Marimuthu, 2013) and Tobacco mosaic virus infection (Sun et al., 2003). This could be due to the effect of Ganoderma constituents in inhibiting the viral replication by interfering with their adsorption, viral integration, assembly and release (Gao et al., 2003). 
Based on the inhibition zone and maximum inhibition per cent of mycelial growth of the pathogen, the mushroom fungi G. lucidum, A. polytricha and $L$. edodes possessing antagonistic activity was assumed to secrete antimicrobial compounds and hence selected for further studies.

Testing the solvent extracted metabolites of selected mushroom fungi ( $G$ lucidum, $A$. polytricha and $L$. edodes) against spore germination and mycelial growth of $C$. capsici

The use of extraction solvents is important to extract antimicrobial components of interest as many of the macro fungi extracted with polar and non polar solvents contained bioactive compounds with antifungal, antibacterial and antiviral activities against human pathogens (Wasser, 2002). In our study different solvents viz., Chloroform, Diethyl ether and Ethyl acetate were used to extract the antimicrobial compounds from 20 day old crude cell free culture filtrates of G. lucidum, L. edodes and A. polytricha. All three extracts used in the study had antimicrobial activity of C. capsici. The results obtained in the present study showed that the Chloroform, Diethyl ether and Ethyl acetate fractions of G. lucidum cell free extracts inhibited spore germination of $C$. capsici both at 12 and 24 hours; with maximum inhibition of spore germination at 24 hours. The Chloroform, Diethyl ether and Ethyl acetate extracted constituents of $G$. lucidum showed spore germination inhibition of $85 \%, 73.75 \%$ and $70.25 \%$ respectively at 12 hours and inhibition of $88 \%, 79 \%$ and 78 $\%$ respectively at 24 hours. In the case of $A$. polytricha, ethyl acetate fractions of metabolites exhibited inhibition of spore germination of $C$. capsici with inhibition of $55.75 \%$ followed by Chloroform and Diethyl ether fractions at 52.75 and 52.5 per cent inhibition respectively at 12 hours. The spore germination inhibition at 24 hours was observed to be $66.25 \%$ in Ethyl acetate fraction followed by Chloroform and Diethyl ether $(59.5 \%$ and $59 \%$ respectively). The chloroform fraction of $L$. edodes inhibited spore germination of $C$. capsici with inhibition of $57.75 \%$ and $67.25 \%$ at 12 and 24 hours respectively. Similarly, the Ethyl acetate fractions and Diethyl ether fractions recorded inhibition of spore germination (56.5\% and $65.25 \%$ respectively) at 12 hours and $(53.25 \%$ and $64.25 \%$ respectively) at 24 hours (Table 2a). Chen and Hyuang (2010) reported that the culture filtrates of Lentinula edodes and Clitocybe nuda completely inhibited the spore germination of Colletotrichum higginsianum. Also, culture filtrates of Ganoderma lucidum inhibited spore germination of Alternaria brassicicola and culture filtrates of Coprinus comatus, $L$. edodes, Tremella aurantialba and $C$. nuda suppressed the germination of Phytophthora capsici.

The agar well diffusion of solvent extracted constituents of cell free culture filtrates of $G$. lucidum, L. edodes and A. polytricha (Table 2b) showed that all the metabolites extracted from all the three solvents (Chloroform, Diethyl ether and Ethyl acetate) at $500 \mathrm{ppm}$ exhibited inhibition of mycelial growth of $C$. capsici. Variations in inhibition of mycelial growth were observed among different solvent extracted metabolites against $C$. capsici. In the present study, among the different solvents, Chloroform extracted metabolites of G. lucidum recorded 40 per cent inhibition of mycelial growth of $C$. capsici followed by Diethyl ether (34.07\% inhibition) and Ethyl acetate fractions (29.25\% inhibition). In the case of L. edodes, Chloroform fractions exhibited 36 per cent inhibition of mycelial growth followed by Ethyl acetate $(32.96 \%)$ and Diethyl ether fractions (31 per cent). The Ethyl acetate fractions followed by Diethyl ether fractions 
of A. polytricha recorded 32.96 and 30 per cent inhibition of mycelial growth respectively followed by Chloroform fractions (22 per cent inhibition). From the study, it is observed that chloroform extracted fractions followed by Diethyl ether and Ethyl acetate fractions of $G$. lucidum showed maximum inhibition of mycelial growth of $C$. capsici with $40 \%, 34.07 \%$ and $29.25 \%$ respectively when compared to other solvent extracted fractions of $L$. edodes and $A$. polytricha which clearly shows the antimicrobial nature of metabolites from $G$. lucidum. Widest inhibitory zone $(33 \mathrm{~mm})$ was obtained with acetone extract from mycelium of Ganoderma lucidum against Pseudomonas aeruginosa (Sheetal Mehta and Savitha Jandaik, 2012).

Variations in antimicrobial activity of $G$. lucidum extracts was observed in different solvent fractions and it is explained that the reason for the differences in their antimicrobial effectiveness may be due to the differences in the molecular weight of the compounds or due to the genetic makeup of the test organisms (Uma Gowrie et al.,2014; Gebreyohannes et.al., 2019). Moreover the Ganoderma compounds identified are mostly Triterpenes (lanostanoid-type triterpene and polyketides (Farnesyl quinone), small peptides (ganodermin) and polysaccharides with antimicrobial properties (Wang and $\mathrm{Ng}$, 2006; Zhang et al., 2015; Basnet et al., 2017). The antifungal agent phellinsin A from Phellinus sp. inhibited the growth of Colletotrichum lagenarium, Pyricularia grisea, Rhizoctonia solani, Aspergillus fumigatus and Trichophyton mentagrophytes (Hwang et al., 2000; Chowdhary et al., 2015). Antibacterial activity of $L$. edodes against Gram negative and Gram positive bacteria viz., Staphylococcus aureus, Bacillus subtilis, Escherichia coli, Klebsiella pneumoniae, Pseudomonas aeruginosa, and Salmonella typhi has been reported (Ishikawa et al., 2001;
Komemushi et al., 1996; Quereshi et al., 2010). In some other studies, crude methanolic extract (100 ppm) from Clitocybe $\mathrm{sp}$, Boletus affinis var. maculosus would exhibited maximum inhibition against Colletotrichum coffaenum (89.08 per cent and 76.69 per cent) followed by Leucocoprinus fragilissimus, Collybia strictipes and Lactarius $\mathrm{sp}$ ( Shahid et al., 2016)

Based on the above studies, G. lucidum possessing maximum antimicrobial activity with respect of inhibition of spore germination and mycelial growth inhibition was taken for further studies.

\section{Testing different concentrations of solvent extracted metabolites of $G$ lucidum against C. capsici}

The antimicrobial metabolites of G. lucidum were extracted using different solvents (chloroform, diethyl ether, ethyl acetate) were made up to different concentrations of 1000,1500 and $2000 \mathrm{ppm}$ to test the desired concentration that could inhibit maximum mycelial growth of $C$. capsici. From the results (Table 3; Plate 2) it is observed that all the solvent extracted antimicrobial metabolites of G. lucidum at $1000 \mathrm{ppm}, 1500$ ppm and $2000 \mathrm{ppm}$ exhibited mycelial growth inhibition of $C$. capsici ranging (43.75 per cent to 60.55 per cent). The Chloroform extracted metabolite of G. lucidum $(60.55 \%)$ followed by Ethyl acetate and Diethyl ether (58.88 \% and $55.47 \%$ respectively) fractions at $2000 \mathrm{ppm}$ inhibited maximum mycelial growth of $C$. capsici. The chloroform extract of Hygrophorus agathosmus and the dichloromethane extract of Suillus collitinus were the most active extracts against both yeast and bacteria (Yamac and Fatma Bilgili, 2006). The chloroform extract (100 $\mu \mathrm{l}$ concentration) of $G$. lucidum basidiocarp showed antibacterial activity against $S$. typhi with inhibition zone of $18 \mathrm{~mm}$ and antifungal 
activity against $C$. albicans with inhibition zone of $17 \mathrm{~mm}$ (Uma Gowrie et al., 2014). Ethyl acetate was found to be the best solvent for extracting antimicrobial substances from $L$. edodes, A. polytricha and $V$. volvaceae which showed inhibition of mycelial growth of Alternaria solani, Colletotrichum capsici, Phytopthora and Rhizoctonia solani (Radhajeyalakshmi et al., 2011). Also ethyl acetate fractions from fruiting body and CFC filtrate condensate of Pisolithus albus exhibited antifungal activities against
Fusarium oxysporum. f. sp. lycopersici, Macrophomina phaseolina and Rhizoconia solani (Ganeshkumar and Krishnamoorthy, 2014). The fruiting body, mycelia and spores of G. lucidum contain ganoderic acid, polysaccharides, triterpenoids, fatty acids, nucleotides, protein, peptides, sterols (Yoon $e t$ al., 1994; Mizuno et al., 1995; Kim et al., 1999; Uma Gowrie et al., 2014) which account for more than 400 bioactive compounds.

Table.1 Screening the antagonistic activity of mushroom fungi against $C$. capsici by dual culture technique

\begin{tabular}{|c|c|c|c|c|}
\hline Treatment & $\begin{array}{l}\text { Colletotrichum capsici } \\
\text { Average radial mycelial } \\
\text { growth }(\mathrm{mm})\end{array}$ & $\begin{array}{l}\text { Mushroom } \\
\text { fungal growth } \\
(\mathbf{m m})\end{array}$ & $\begin{array}{l}\text { Inhibition } \\
\text { zone (mm) }\end{array}$ & $\begin{array}{c}\text { \%inhibition over } \\
\text { control }\end{array}$ \\
\hline Ganoderma lucidum & $\begin{array}{l}40.67^{a b} \\
(39.58)\end{array}$ & $\begin{array}{l}44.40^{c} \\
(41.78)\end{array}$ & 4.86 & $\begin{array}{l}54.81^{\mathrm{ab}} \\
(47.76)\end{array}$ \\
\hline $\begin{array}{l}\text { Auricularia } \\
\text { polytricha }\end{array}$ & $\begin{array}{l}41.67^{b} \\
(40.16)\end{array}$ & $\begin{array}{l}45.33^{\mathrm{c}} \\
(42.32)\end{array}$ & 2.76 & $\begin{array}{l}53.70^{b} \\
(47.12)\end{array}$ \\
\hline Lentinus edodes & $\begin{array}{l}49.00^{\text {cd }} \\
(44.43)\end{array}$ & $\begin{array}{l}36.00^{a} \\
(36.87)\end{array}$ & 4.86 & $\begin{array}{l}45.55^{\text {cd }} \\
(42.45)\end{array}$ \\
\hline $\begin{array}{l}\text { Pycnoporus } \\
\text { sanguineus }\end{array}$ & $\begin{array}{l}38.33^{\mathrm{a}} \\
(38.23)\end{array}$ & $\begin{array}{l}51.70^{\mathrm{d}} \\
(45.97)\end{array}$ & 0 & $\begin{array}{l}57.41^{a} \\
(49.26)\end{array}$ \\
\hline Coprinus sinensis & $\begin{array}{l}54.00^{\mathrm{e}} \\
(47.29)\end{array}$ & $\begin{array}{l}36.00^{\mathrm{a}} \\
(36.87)\end{array}$ & 0 & $\begin{array}{l}40.00^{\mathrm{e}} \\
(39.23)\end{array}$ \\
\hline $\begin{array}{l}\text { Schizophyllum } \\
\text { commune }\end{array}$ & $\begin{array}{l}47.00^{\mathrm{c}} \\
(43.28)\end{array}$ & $\begin{array}{l}39.00^{b} \\
(38.65)\end{array}$ & 0 & $\begin{array}{l}47.78^{c} \\
(43.73)\end{array}$ \\
\hline Volvariella volvaceae & $\begin{array}{l}51.37^{\mathrm{de}} \\
(45.74)\end{array}$ & $\begin{array}{l}35.70^{\mathrm{a}} \\
(36.69)\end{array}$ & 2.83 & $\begin{array}{l}42.92^{\mathrm{de}} \\
(40.93)\end{array}$ \\
\hline Trametes versicolor & $\begin{array}{l}50.73^{\mathrm{de}} \\
(45.40)\end{array}$ & $\begin{array}{l}38.30^{b} \\
(38.23)\end{array}$ & 1.10 & $\begin{array}{l}43.63^{\mathrm{de}} \\
(41.34)\end{array}$ \\
\hline Control & $\begin{array}{l}90.00^{f} \\
(71.57)\end{array}$ & - & - & $\begin{array}{c}0.00^{\mathrm{f}} \\
(0.57)\end{array}$ \\
\hline SEd & 2.9511 & 0.5156 & & \\
\hline$C D(p=0.05)$ & 1.4047 & 1.0930 & & \\
\hline
\end{tabular}

Values are the mean of three replications. Means followed by a common letter are not significantly different at $5 \%$ level by DMRT.Values in parenthesis are arcsine transformed values 
Table.2a Effect of solvent fractions of culture filtrates of selected mushroom fungi on spore germination of $C$. capsici

\begin{tabular}{|c|c|c|c|c|c|c|c|c|c|c|c|c|c|c|c|c|c|c|}
\hline \multirow{4}{*}{$\begin{array}{c}\text { Mushroom } \\
\text { fungi }\end{array}$} & \multicolumn{18}{|c|}{ Solvent extracted metabolites } \\
\hline & \multicolumn{6}{|c|}{ Ethyl acetate } & \multicolumn{6}{|c|}{ Chloroform } & \multicolumn{6}{|c|}{ Diethyl ether } \\
\hline & \multicolumn{2}{|c|}{6 hours } & \multicolumn{2}{|c|}{12 hours } & \multicolumn{2}{|c|}{24 hours } & \multicolumn{2}{|c|}{6 hours } & \multicolumn{2}{|c|}{12 hours } & \multicolumn{2}{|c|}{24 hours } & \multicolumn{2}{|c|}{ 6hours } & \multicolumn{2}{|c|}{12 hours } & \multicolumn{2}{|c|}{24 hours } \\
\hline & SG & PI & SG & PI & SG & PI & $\begin{array}{l}\text { S } \\
\text { G }\end{array}$ & PI & SG & PI & SG & PI & $\begin{array}{l}\mathbf{S} \\
\mathbf{G}\end{array}$ & PI & SG & PI & SG & PI \\
\hline $\begin{array}{c}\text { Ganoderma } \\
\text { lucidum }\end{array}$ & - & $\begin{array}{c}100^{\mathrm{a}} \\
(89.19)\end{array}$ & $\begin{array}{c}29.75^{\mathrm{a}} \\
(33.05)\end{array}$ & $\begin{array}{c}70.25^{\mathrm{a}} \\
(56.95)\end{array}$ & $\begin{array}{l}22.00^{\mathrm{a}} \\
(27.97)\end{array}$ & $\begin{array}{c}78.0^{\mathrm{a}} \\
(62.03)\end{array}$ & - & $\begin{array}{c}100^{\mathrm{a}} \\
(89.19)\end{array}$ & $\begin{array}{l}15.00^{\mathrm{a}} \\
(22.79)\end{array}$ & $\begin{array}{c}85.0^{\mathrm{a}} \\
(67.21)\end{array}$ & $\begin{array}{c}12.0^{\mathrm{a}} \\
(20.27)\end{array}$ & $\begin{array}{c}88.0^{\mathrm{a}} \\
(69.73)\end{array}$ & - & $\begin{array}{c}100^{\mathrm{a}} \\
(89.19)\end{array}$ & $\begin{array}{l}26.25^{\mathrm{a}} \\
(30.82)\end{array}$ & $\begin{array}{c}73.75^{a} \\
(59.18)\end{array}$ & $\begin{array}{l}21.25^{\mathrm{a}} \\
(27.45)\end{array}$ & $\begin{array}{c}79.0^{\mathrm{a}} \\
(62.73)\end{array}$ \\
\hline $\begin{array}{c}\text { Auricularia } \\
\text { polytricha }\end{array}$ & - & $\begin{array}{c}100^{\mathrm{a}} \\
(89.19)\end{array}$ & $\begin{array}{l}44.25^{b} \\
(41.70)\end{array}$ & $\begin{array}{l}55.75^{b} \\
(48.30)\end{array}$ & $\begin{array}{l}33.75^{b} \\
(35.52)\end{array}$ & $\begin{array}{l}66.25^{b} \\
(54.48)\end{array}$ & - & $\begin{array}{c}100^{\mathrm{a}} \\
(89.19)\end{array}$ & $\begin{array}{l}47.25^{\mathrm{c}} \\
(43.42)\end{array}$ & $\begin{array}{l}52.75^{c} \\
(46.58)\end{array}$ & $\begin{array}{c}40.5^{\mathrm{c}} \\
(39.52)\end{array}$ & $\begin{array}{c}59.5^{\mathrm{c}} \\
(50.48)\end{array}$ & - & $\begin{array}{c}100^{\mathrm{a}} \\
(89.19)\end{array}$ & $\begin{array}{c}47.5^{b} \\
(43.57)\end{array}$ & $\begin{array}{c}52.5^{b} \\
(46.43)\end{array}$ & $\begin{array}{l}41.00^{c} \\
(39.82)\end{array}$ & $\begin{array}{c}59.0^{c} \\
(50.18)\end{array}$ \\
\hline $\begin{array}{c}\text { Lentinus } \\
\text { edodes }\end{array}$ & - & $\begin{array}{c}100^{\mathrm{a}} \\
(89.19)\end{array}$ & $\begin{array}{c}43.5^{b} \\
(41.27)\end{array}$ & $\begin{array}{c}56.5^{b} \\
(48.73)\end{array}$ & $\begin{array}{l}34.75^{b} \\
(36.12)\end{array}$ & $\begin{array}{l}65.25^{b} \\
(53.88)\end{array}$ & - & $\begin{array}{c}100^{\mathrm{a}} \\
(89.19)\end{array}$ & $\begin{array}{l}42.25^{b} \\
(40.54)\end{array}$ & $\begin{array}{l}57.75^{b} \\
(49.46)\end{array}$ & $\begin{array}{l}32.75^{b} \\
(34.91)\end{array}$ & $\begin{array}{l}67.25^{b} \\
(55.09)\end{array}$ & - & $\begin{array}{c}100^{\mathrm{a}} \\
(89.19)\end{array}$ & $\begin{array}{l}46.75^{b} \\
(43.14)\end{array}$ & $\begin{array}{l}53.25^{b} \\
(46.86)\end{array}$ & $\begin{array}{l}35.75^{b} \\
(36.72)\end{array}$ & $\begin{array}{l}64.25^{b} \\
(53.28)\end{array}$ \\
\hline Control & - & $\begin{array}{c}100^{\mathrm{a}} \\
(89.19)\end{array}$ & $\begin{array}{c}54.0^{c} \\
(47.29)\end{array}$ & $\begin{array}{c}46.0^{c} \\
(42.71)\end{array}$ & $\begin{array}{c}83.0^{d} \\
(65.65)\end{array}$ & $\begin{array}{c}17.0^{\mathrm{d}} \\
(24.35)\end{array}$ & - & $\begin{array}{c}100^{\mathrm{a}} \\
(89.19)\end{array}$ & $\begin{array}{c}54.0^{d} \\
(47.29)\end{array}$ & $\begin{array}{c}46.0^{d} \\
(42.71)\end{array}$ & $\begin{array}{c}83.0^{\mathrm{e}} \\
(65.65)\end{array}$ & $\begin{array}{c}17.0^{\mathrm{e}} \\
(24.35)\end{array}$ & - & $\begin{array}{c}100^{\mathrm{a}} \\
(89.19)\end{array}$ & $\begin{array}{c}54.0^{c} \\
(47.29)\end{array}$ & $\begin{array}{c}46.0^{c} \\
(42.71)\end{array}$ & $\begin{array}{c}83.0^{\mathrm{e}} \\
(65.65)\end{array}$ & $\begin{array}{c}17.0^{\mathrm{e}} \\
(24.35)\end{array}$ \\
\hline $\begin{array}{c}\text { Control } \\
\text { (without } \\
\text { metabolite) }\end{array}$ & - & $\begin{array}{c}100^{\mathrm{a}} \\
(89.19)\end{array}$ & $\begin{array}{c}47.0^{b} \\
(43.28)\end{array}$ & $\begin{array}{c}53.0^{b} \\
(46.72)\end{array}$ & $\begin{array}{c}77.0^{c} \\
(61.34)\end{array}$ & $\begin{array}{c}23.0^{c} \\
(28.66)\end{array}$ & - & $\begin{array}{c}100^{\mathrm{a}} \\
(89.19)\end{array}$ & $\begin{array}{c}47.0^{c} \\
(43.28)\end{array}$ & $\begin{array}{c}53.0^{c} \\
(46.72)\end{array}$ & $\begin{array}{c}77.0^{d} \\
(61.34)\end{array}$ & $\begin{array}{c}23.0^{d} \\
(28.66)\end{array}$ & - & $\begin{array}{c}100^{\mathrm{a}} \\
(89.19)\end{array}$ & $\begin{array}{c}47.0^{b} \\
(43.28)\end{array}$ & $\begin{array}{c}53.0^{b} \\
(46.72)\end{array}$ & $\begin{array}{c}77.0^{d} \\
(61.34)\end{array}$ & $\begin{array}{c}23.0^{d} \\
(28.66)\end{array}$ \\
\hline SEd & - & & 1.7369 & & 1.4720 & & - & & 6.5256 & & 1.0288 & & - & & 1.2179 & & 1.0878 & \\
\hline$C D(p=0.05)$ & - & & 3.7021 & & 3.1374 & & - & & $\begin{array}{c}13.909 \\
1\end{array}$ & & 2.1928 & & - & & 2.5960 & & 2.3186 & \\
\hline
\end{tabular}

Where, SG- No. of spores germinated, PI- Percent inhibition of spore germination. Values are the mean of four replications. Means followed by a common letter are not significantly different at $5 \%$ level by DMRT. Values in parenthesis are arcsine transformed values 
Table.2b Antimicrobial activity of solvent extracted metabolites of selected mushroom fungi against $C$. capsici by agar well diffusion technique

\begin{tabular}{|c|c|c|c|}
\hline Mushroom fungi & Solvents used & Average mycelial growth (mm) & \%inhibition over control \\
\hline \multirow{6}{*}{ Ganoderma lucidum } & \multirow[t]{2}{*}{ Ethyl acetate } & $63.67^{\mathrm{ef}}$ & $29.25^{\mathrm{ef}}$ \\
\hline & & $(52.93)$ & (32.74) \\
\hline & \multirow[t]{2}{*}{ Chloroform } & $54.00^{\mathrm{a}}$ & $40.00^{\mathrm{a}}$ \\
\hline & & $(47.29)$ & (39.23) \\
\hline & \multirow[t]{2}{*}{ Diethyl ether } & $59.33^{\mathrm{c}}$ & $34.07^{\mathrm{c}}$ \\
\hline & & $(50.38)$ & $(35.71)$ \\
\hline \multirow{6}{*}{ Lentinus edodes } & \multirow[t]{2}{*}{ Ethyl acetate } & $61.00^{\text {cde }}$ & $32.00^{\text {cde }}$ \\
\hline & & (51.35) & $(34.45)$ \\
\hline & \multirow[t]{2}{*}{ Chloroform } & $57.00^{b}$ & $36.00^{b}$ \\
\hline & & (49.02) & (36.87) \\
\hline & \multirow[t]{2}{*}{ Diethyl ether } & $62.00^{\mathrm{def}}$ & $31.00^{\mathrm{def}}$ \\
\hline & & (51.94) & $(33.83)$ \\
\hline \multirow{6}{*}{ Auricularia polytricha } & \multirow[t]{2}{*}{ Ethyl acetate } & $60.33^{\mathrm{cd}}$ & $32.96^{\mathrm{cd}}$ \\
\hline & & (50.96) & (35.04) \\
\hline & \multirow[t]{2}{*}{ Chloroform } & $70.00^{\mathrm{g}}$ & $22.00^{\mathrm{g}}$ \\
\hline & & $(56.79)$ & $(27.97)$ \\
\hline & \multirow[t]{2}{*}{ Diethyl ether } & $63.00^{\mathrm{ef}}$ & $30.00^{\text {ef }}$ \\
\hline & & (52.54) & (33.21) \\
\hline \multirow[t]{2}{*}{ Control } & & $90.00^{\mathrm{h}}$ & $0.00^{\mathrm{h}}$ \\
\hline & & (71.57) & $(0.51)$ \\
\hline SEd & & 0.9661 & \\
\hline $\mathrm{CD}(\mathrm{p}=\mathbf{0 . 0 5})$ & & 2.0152 & \\
\hline
\end{tabular}

Values are the mean of three replications

Means followed by a common letter are not significantly different at 5\%level by DMRT

Values in parenthesis are arcsine transformed values 
Table.3 Testing the different concentrations of solvent extracted metabolites of G. lucidum against $C$. capsici

\begin{tabular}{|c|c|c|c|c|}
\hline Treatment & Solvent & Concentation (ppm) & Average mycelial growth(mm) & \%inhibition over control \\
\hline \multirow[t]{9}{*}{ Ganoderma lucidum } & \multirow[t]{3}{*}{ Ethyl acetate } & 1000 & $50.62^{\mathrm{f}}(45.36)$ & $43.75^{\mathrm{f}}(41.41)$ \\
\hline & & 1500 & $48.07^{\mathrm{e}}(43.89)$ & $46.58^{\mathrm{e}}(43.04)$ \\
\hline & & 2000 & $37.00^{\mathrm{b}}(37.46)$ & $58.88^{\mathrm{b}}(50.11)$ \\
\hline & \multirow[t]{3}{*}{ Chloroform } & 1000 & $45.10^{\mathrm{d}}(42.19)$ & $49.88^{\mathrm{d}}(44.93)$ \\
\hline & & 1500 & $40.17^{c}(39.33)$ & $55.36^{\mathrm{c}}(48.08)$ \\
\hline & & 2000 & $35.52^{\mathrm{a}}(36.58)$ & $60.55^{\mathrm{a}}(51.09)$ \\
\hline & \multirow[t]{3}{*}{ Diethyl ether } & 1000 & $50.15^{\mathrm{f}}(45.09)$ & $44.27^{\mathrm{f}}(41.71)$ \\
\hline & & 1500 & $44.50^{\mathrm{d}}(41.84)$ & $50.55^{\mathrm{d}}(45.32)$ \\
\hline & & 2000 & $40.07^{c}(39.27)$ & $55.47^{\mathrm{c}}(48.14)$ \\
\hline Control & & & $90.00^{\mathrm{g}}(71.57)$ & $0.00^{\mathrm{g}}(0.44)$ \\
\hline SEd & & & 0.5104 & \\
\hline $\mathrm{CD}(\mathrm{p}=0.05)$ & & & 1.0425 & \\
\hline
\end{tabular}

Values are the mean of four replications. Means followed by a common letter are not significantly different at $5 \%$ level by DMRT. Values in parenthesis are arcsine transformed values

Plate.1 Invitro effect of antagonistic activity of mushroom fungi against $C$. capsici by dual culture technique

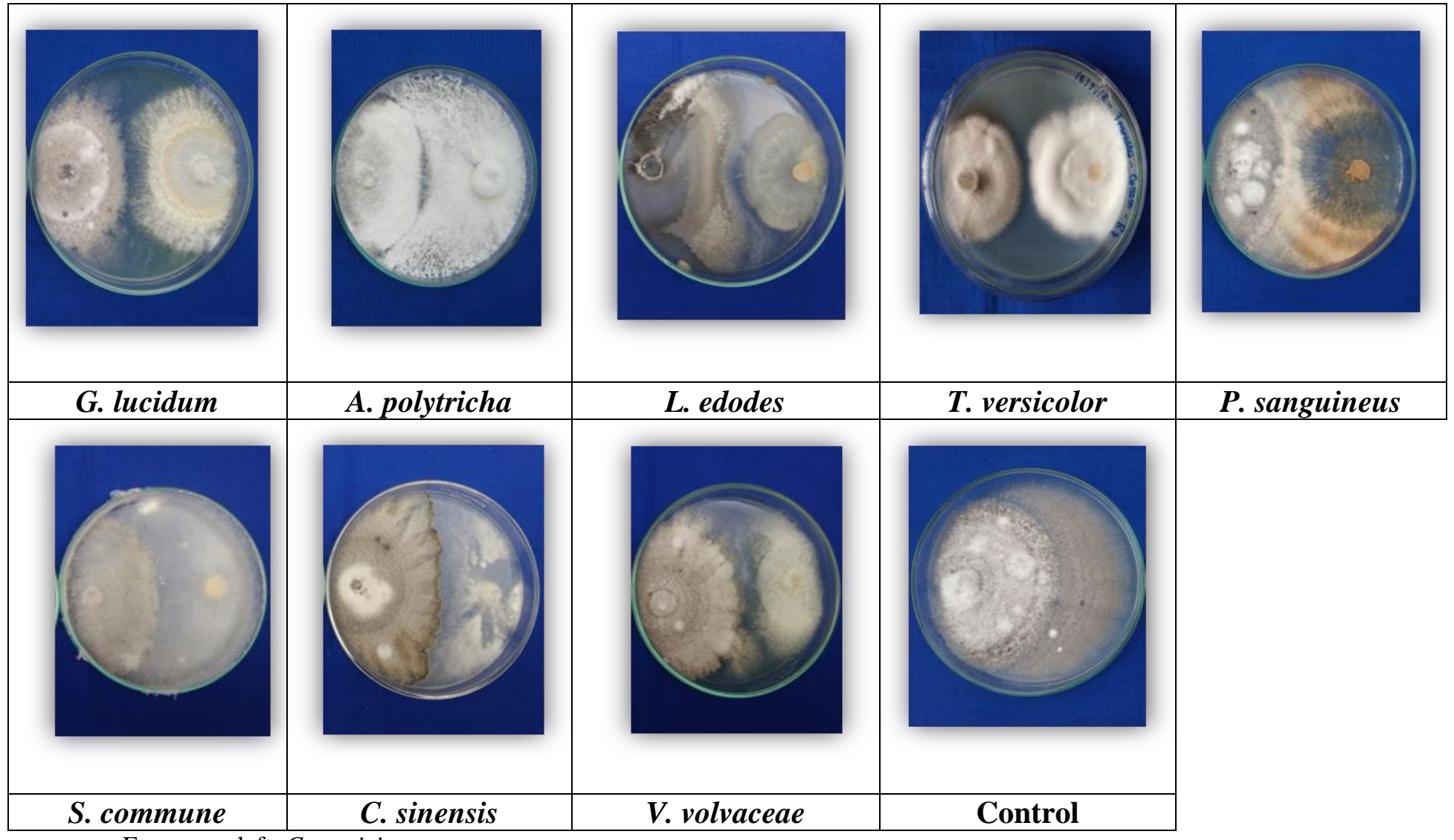

Fungus on left: C.capsici

Fungus on right: Mushroom fungus 
Plate.2 Antimicrobial activity of different solvent extracted fractions of Cell free culture filtrates of G. lucidum against C. capsici

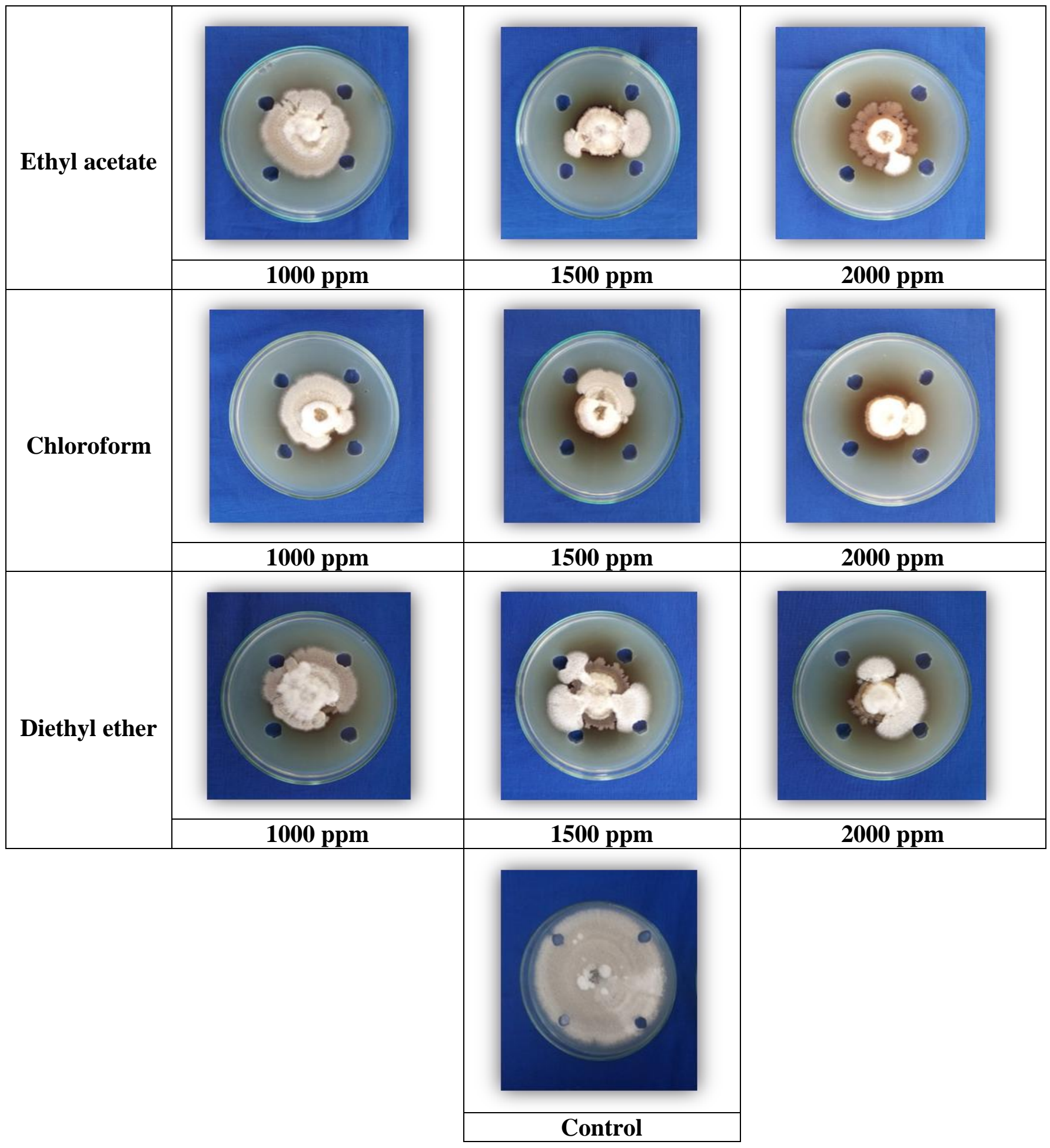


Since, the chloroform extracted antimicrobial metabolites of G. lucidum at 2000 ppm showed maximum antimicrobial activity as evidenced by the above results, further work proceeded with higher concentrations using chloroform as solvent that could show maximum mycelial growth inhibition.

Globally research is focused on the identification of antimicrobial molecules from fungi, bacteria and plants to manage plant diseases in a green channel system to mitigate the environmental hazards and pollution by indiscriminate use of fungicides. This study implies that all the mushroom fungi screened against $C$. capsici possessed antagonistic activity either with formation of inhibition zone, thick mat of mycelium and hyperparasitisation. Among these, the macrofungi Ganoderma lucidum with maximum secretion of bioactive compounds belonging to several chemical groups needs to be identified and has great scope for developing fungicides against broad group of plant pathogens.

\section{Acknowledgement}

The authors thank the ICAR - AICRP scheme on Mushroom and UGC- SAP DRS 1 scheme for supporting the research work.

\section{References}

Akhter, N., Begum, M.F., Alam, M.S. 2006. Inhibitory effect of different plant extracts, cow dung and cow urine on conidial germination of Bipolaris sorokiniana. J. Bio-sci 14, 87-92.

Anonymous, 1943. The slide germination method of evaluating protectant fungicides. Phytopathology, 33:627632.

Badalyan, S. M., Gharibyan, N. G., Innocenti, G. 2014. Antifungal/Antagonistic Activity of Different Ganoderma Collections against Plant Pathogenic
Fungi and Their Antagonists. 8th internation conference on mushroom biology and mushroom, 4.

Bansal, R.D. and Grover, R.K. 1969. Reaction of chilli (Capsicum frutescens) varieties to Colletotrichum capsici. J.Res. Ludhiana 6 (2): 345-348.

Basnet, B.B., Li Liua, Li Bao and Hongwei Liu. 2017. Current and future perspective on antimicrobial and anti-parasitic activities of Ganoderma sp.: an update. Mycology, vol. 8, No. 2, 111-124.

Dennis, C and Webster, J. 1971. Antagonistic properties of species-groups of Trichoderma: II. Production of volatile antibiotics. Transactions of the British Mycological Society, 57(1), 41-IN44.

Ganesh Kumar and Krishnamoorthy, A. S. 2014. Exploration of Antifungal Bioactive Compounds of Pisolithus tinctorius (Pers) Coker against Some Soil Borne Plant Pathogens. PhD thesis, 1.

Gebreyohannes, G., Andrew Nyerere, Christine Bii, and Desta Berhe Sbhatu. 2019. Evidence-Based Complementary and Alternative Medicine Volume 2019, Article ID 6212673, 7 pages.

Hatvani, N. 2001. Antibacterial effect of the culture fluid of Lentinus edodes mycelium grown in submerged liquid culture. International Journal of Antimicrobial Agents, 17(1), 71-74.

Feleke, H.T. and Anila Doshi. 2017. Bioactive compounds of antimicrobial nature from Indian wild mushrooms. Indian J. of Natural Products and Resources. 8(3): 254-262.

Hwang, E.I., Yun, B., Kim Y.K., Kwon, B. M., Kim, H.G., Lee, H.B., Jeong, W., Kim, S.V. 2000. Phellinsin A, a novel chitin synthase inhibitor produced by Phellinus sp. Journal of Antibiotics 53: 903-11.

Ishikawa, N.K., Kasuya, M.C.M., Vanetti, M.C.D. 2001Antimicrobial activity of Lentinula edodes grown in liquid medium. Brazilian Journal of Microbiology. 32: 206-210. 
Jeeva, S. and Krishnamoorhy, A.S. 2018. Antifungal potential of Myco-molecules of Coprinopsis cinerea (Schaeff) S. Gray s.lat against Fusarium spp, Madras Agric J., 105(1-3): 56-60.

Jeffries, P., Dodd, J.C., Jegerand, M.J., Plumbley, R.A. 1990. The biology and control of Colletotrichum species on tropical fruit crops, Plant Pathology, 39(3): 343-36.

Chen, JT. and Huang, JW. 2010. Antimicrobial Activity of Edible Mushroom Culture Filtrates on Plant Pathogens Plant Pathology Bulletin 19: 261-270.

Gao, Y., Zhou, S., Huang, M., Xu, A. 2003. Antibacterial and Antiviral value of the Genus Ganoderma P. Karst. Species (Aphyllophoromycetideae): A Review. International Journal of Medicinal Mushrooms. 5(3): 235-246.

Kim, H.W., Kim, B.K. 1999. Biomedical triterpenoidsof Ganoderma lucidum (Curt: $\quad$ Fr.) P. Karst. (Aphyllophoromycetideae). Int. J. Med.Mushrooms, 1: 121-138.

Komemushi, S., Yamamoto, Y. and Fujita, T.T.1996. Purification and identification of antimicrobial substances produced by Lentinus edodes. Journal of Antibacterial and Antifungal Agents. Vol. 24, no. 1, Pp. 21-25

Lindequist, U., Niedermeyer, T. H., and Julich, W.D. 2005. The pharmacological potential of mushrooms. EvidenceBased Complementary and Alternative Medicine, 2(3), 285-299.

Liu, F., Tang, G., Xiaojuan Zheng, Ying Li. 2016, Molecular and Phenotypic characterization of Colletotrichum species associated with anthracnose disease in peppers from Sichuan Province, China. Nature Sci. Rep. 6: 32761.

Liu, F., Tang, G., Xiaojuan Zheng, Ying Li. 2016. Molecular and Phenotypic characterization of Colletotrichum species associated with anthracnose disease in peppers from Sichuan Province, China. Nature Sci. Rep.
6:32761.

Mizuno, T. 1995. Reishi, Ganoderma lucidum andGanoderma tsugae: bioactive substances and medicinal effects. Food Rev. Int., 11:151-166.

Chowdhury, M.M.H., Khadizatul Kubra and Sheikh Rashel Ahme. 2015. Screening of antimicrobial, antioxidant properties and bioactive compounds of some edible mushrooms cultivated in Bangladesh. Annals of Clinical Microbiology and Antimicrobials: 14:8.

Yamac, $\mathrm{M}$ and Fatma Bilgili. 2006. Antimicrobial Activities of Fruit Bodies and/or Mycelial Cultures of Some Mushroom Isolates. Pharmaceutical Biology, 44:9, 660-667, DOI:10.1080/13880200601006897.

Radhajeyalakshmi, R., Velzhahan, R., Prakasam, V. 2011. In vitro evaluation of solvent extracted compounds from edible macromycetes agianst phytopathogenic fungi. Archives of Phytopathology and Plant Protection. Vol 1: 1-8.

Reis, F. S., Pereira, E., Barros, L., Sousa, M. J., Martins, A., and Ferreira, I.C. 2011. Biomolecule profiles in inedible wild mushrooms with antioxidant value. Molecules, 16(6), 4328-4338.

Roberts, P.D., Pernezny, K., Kucharek, T.A. 2001. Anthracnose caused by Colletotrichum sp. on pepper [online]. Journal of University of Florida/Institute of Food and Agricultural Sciences.

Rouhana-Toubi, A., Wasser, S.P., and Fares, F. 2015. The shaggy ink cap medicinal mushroom, Coprinus comatus (higher Basidiomycetes) extract induces apoptosis in ovarian cancer cells via extrinsic and intrinsic apoptotic pathways. Int $J$ Med Mushrooms, 17(12), 1127-1136.

Quereshi, S., Pandey, A.K., Sandhu, S.S. 2010. Evaluation of antibacterial activity of different Ganoderma lucidum extracts. People's Journal of Scientific Research 9 Vol. 3(1): 2010: 9- 13

Sajeena, A. and Marimuthu, T. 2013. Efficacy, 
stability and persistence of Ganosol, a Ganoderma based fungicide against plant pathogens. The Journal of Plant Protection Sciences, 5(1): 17-25.

Sangeetha, C., Krishnamoorthy, A., Nakkeeran, S., Ramakrishnan, S. and Amirtham, D. 2015. Evaluation of bioactive compounds of Ophiocordyceps sinensis [Berk.] Sacc. against Fusarium spp. Biochem. Cell. Arch, 15(1), 431-435.

Shahid, A.A., Asif, M., Shahbaz, M., and Ali, M. 2016. Antifungal Potential of Ganoderma lucidum Extract against Plant Pathogenic Fungi of Calendula Officinalis L. Paper presented at the 5th International Conference on Biological, Chemical and Environmental Sciences (BCES-2016) March.

Sharma, G. and Shenoy BD. 2014. Colletotrichum fructicola and $C$. siamense are involved in chilli anthracnose in India. Archives of Phytopathology and Plant Protection 47:1179-1194.

Sheetal, M. and Savita Jandaik. 2012. In vitro comparative evaluation of antibacterial activity of fruiting body and mycelial extracts of Ganoderma lucidum against pathogenic bacteria. Journal of pure and applied Microbiology, December Vol. 6(4), p. 1997-2001

Stroke, J.E. and Ridgway, G.L. 1980. Clinical bacteriology, Edward Arnold Ltd. London, p, 143
Sun, H., Zhao, C G., Tong, X., Qi, Y.P. 2003. A lectin with mycelia differentiation and anti phytovirus activities from the edible Mushroom Agrocybe aegerita. Journal of Biochemical Molecular Biology 36: 214-22.

Uma Gowrie, S., Chathurdevi, G., Rani, K. 2014 .Evaluation of Bioactive Potential of Basidiocarp Extracts of Ganoderma lucidum International Journal of Pharmaceutical Research \& Allied Sciences, Volume 3, issue 1 (2014),3646.

Vincent, JM. 1947. Distortion of fungal hyphae in the presence of certain inhibitors. Nature 159:850-850.

Wang, H.X. and Ng, T.B. 2006. A laccase from the medicinal mushroom Ganoderma lucidum. Applied Microbiol. Biotechnol., 72:508-513

Wasser, SP. 2002. Review of Medicinal Mushrooms Advances: Good news from old Allies. Herbal Gram 56: 28-33.

Yoon, S.Y., Eo, S.K., Lee, C.K., Han, S.S. 1994. Antimicrobial activity of Ganoderma lucidum extract alone and in combination with someantibiotics. Archieves of Pharmacal Research, 17: 438-442.

Zhang, SS., Wang, YG., Ma, QY., Huang, SZ., Hu, LL., Dai, HF., Yu, ZF., Zhao, YX. 2015. Three new lanostanoids from the mushroom Ganoderma tropicum. Molecules. 20: 3281-3289.

\section{How to cite this article:}

Priya, K., G. Thiribhuvanamala, A. Kamalakannan and Krishnamoorthy, A.S. 2019. Antimicrobial Activity of Biomolecules from Mushroom Fungi against Colletotrichum capsici (Syd.) Butler and Bisby, the Fruit Rot Pathogen of Chilli. Int.J.Curr.Microbiol.App.Sci. 8(06): 1172-1186. doi: https://doi.org/10.20546/ijcmas.2019.806.145 